Available online at: http:// http://tsdr.psdku.unpad.ac.id

Tourism and Sustainable Development Review Journal (TSDR)

ISSN 2722-2152 (online)

Volume 1 Number 2 (2020): 65-75

\title{
West Java's Fashion Diplomacy to South Australia: A Model of Sister Province Cooperation
}

\author{
Selma Elfirda Karamy \\ Universitas Padjadjaran
}

\begin{abstract}
Sister Province is a concept that describes inter sub-national cooperation from two different countries. West Java Province, as one of the three provinces with the largest population in Indonesia, has built a Sister Province cooperation with South Australia. This Sister Province cooperation has been established from 1997 and revitalized during the leadership of the 14th Governor of West Java, Ahmad Heryawan, in 2015. The revitalization of West-South-South Java cooperation began with the signing of a Memorandum of Understanding (MoU) containing work plans in both regions in various fields. In the MoU, West Java and South Australia collaborated in the arts and culture, which is related to the modest fashion. The realization of the West Java and South Australia Sister Province was the cooperation of Bandung Islamic Fashion Institute (IFI) as the first Muslim fashion school in Indonesia, and Technical and Further Education (TAFE) as vocational schools and training in South Australia. This study uses the paradiplomacy theory and the sister province concept as analytical tools. The research was conducted to know how the process and the implementation of IFI and TAFE cooperation as a form of Sister Province Cooperation. The research method used is descriptive qualitative research with literature studies. This research resulted in the cooperation of the Sister Province of West Java-South Australia through IFI and TAFE running quite well, namely by the realization of scientific exchanges and fashion show collaborations between the two institutions. However, other cooperation plans have not been realized and require both parties and the government to assist in the preparation of realization and achieve effective and profitable cooperation.
\end{abstract}

Keywords: Paradiplomacy, Islamic Fashion, Sister Province Cooperation

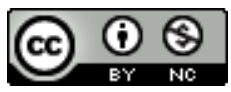

This is an open access article under the CC-BY-NC-SA license.

\section{INTRODUCTION}

Research Background

The complexity of interactions between actors in the international system has led to the growing phenomenon of globalization. This situation gave rise to non-traditional actors who increasingly dominated the development of cross-border activities in various fields. International relations can also be viewed as 'inter-cultural relations' in that every nation-state has its cultural ties and helped create interdependence (Kim, 2017:305)

Relations between national borders, especially in terms of economics, have contributed to a Globalization Concept in International Relations studies. Globalization emerged in the twentieth century by the rise of the international economy. However, the beginning of the emergence of globalization has existed since humans began to recognize trade between countries. In the 20th

Corresponding author

selmaelkamy@gmail.com

DOI: https://doi.org/10.31098/tsdr.v1i2.5

Research Synergy Foundation 
century, globalization grew increasingly accompanied by a rapid flow of technological developments.

With the high complexity of globalization and the implementation of diplomacy, the state is no longer the main actor in international relations but also non-state actors such as sub-state or commonly known as government, provincial institutions, and cities in a country. This type of diplomacy is better known as Sister City or Sister Province.

Based on the Circular of the Minister of Foreign Affairs No. 193/1652 / PUOD / 1993 Dated 26 April 1993 regarding the Procedures for the Establishment of Cooperative relations Inter-City (Sister City) and the Inter-Province (Sister Province) within countries or abroad, that the establishment of Sister Province and Sister City cooperation must be based on several criteria as follows:

- The existence of equal position and administrative status

- There are similarities in magnitude and function

- The existence of similarity characteristics

- The existence of similarity problems

- The existence of transferable knowledge and technology

- The existence of complementarity between the two parties in the economic field, to cause the flow of goods between the two parties.

The implementation of Sister City is also regulated in the Regulation of the Minister of Foreign Affairs Number: 09 / A / KP / XII / 2006/01 dated December 28, 2006, concerning General Guidelines for Procedures for Relations and Foreign Cooperation by Regional Governments. In the regulation p.25, it is explained that: Cooperation between the Regional Government and the Regional Government abroad (Sister Province / Sister City) is carried out with a country that has diplomatic relations with the Republic of Indonesia, does not disturb domestic political and security stability, and is based on the principle of respecting the sovereignty of the Republic of Indonesia, equality of position, not imposing the will, providing benefits and mutual benefits and not leading to interference in their respective internal affairs.

Paradiplomacy is the implication of Regional Autonomy or Decentralization by the central government, the granting of authority and rights to carry out international cooperation for local actors with local actors in other countries through international relations. Besides, paradiplomacy is also considered effective because local actors have an understanding of local communities in a sub-state. Thus the interaction and activities of international relations are focused on regional development from various aspects of people's lives.

In the formation of the Sister Province and Sister City a form of the cooperation agreement is required the proposal to form cooperative relations then submitted to the Ministry of Home Affairs to obtain approval from the Minister of Foreign Affairs, then must be phased before the inauguration in the form of the Cooperation Relationship Sign. The cooperative relations between the two regional governments allows the opportunity to exchange the knowledge and experience of development management in fields that are cooperated, encourage the growth of initiatives and the active role of municipal, community and private governments, strengthen the friendship between the government and the two parties and the opportunity to exchange culture to enrich regional culture (Oetomo, nd). 
The diplomacy of Indonesia and Australia has no longer focuses on the main actors of the country as the main actors in conducting diplomacy or international cooperation, but the state has given the freedom to the sub-state or institutions under the state to conduct diplomacy and international cooperation. This cooperation is organized between Bandung Islamic Fashion Institute and Technical and Further Education (TAFE). TAFE is located in Australia and is the largest education sector and training sector in Australia. The Islamic Fashion Institute (IFI) is the first Islamic fashion college in Indonesia, located in Bandung, Jawa Barat with an Indonesian National Work Competency Standards (SKKNI) curriculum specifically based on Islamic rules.

Indonesia, as the largest Muslim population country in the world, is a distinct advantage for Indonesia. Various kinds of Islamic activities can be reflected in what is done by Indonesia. Not only can it be seen from the political, social and Islamic culture that is Indonesian but also specifically in the field of Fashion, Indonesia today Indonesia begins to develop and introduce Muslim fashion products to the international world to take economic, social and cultural opportunities especially in the Muslim clothing industry. Data on the contribution of Muslim clothing in the world according to the State of the Global Islamic Economic in 2018 amounting to 320 \$billion, this data shows that there is an opportunity for Indonesia to acquire as a center of Muslim fashion in the world((MINA), 2017).

Indonesia in terms of exports of Muslim fashion products are still lagging behind Turkey and Bangladesh at 7.2 billion USD, with the first place being occupied by Bangladesh with 22 billion USD and second, Turkey with 14 billion USD, followed by Indonesia ((MINA), 2017 ) Indonesia has become one of the countries ranked first in terms of exports of Muslim fashion products. With this collaboration between IFI and TAFE, Indonesia is expected to be able to encourage a variety of innovations in the field of Muslim fashion, especially starting from Bandung IFI colleges that collaborate with TAFE in southern Australia. This collaboration can also be seen from the implementation of the paradiplomacy then of course where the role of diplomacy by the central government is now being taken over by regional governments and local regional actors who work together with other regions in the realm of international relations.

Problem Identification

The identification of the problems that arise based on the background above are as follows:

Cooperation of the Institute of Fashion Islamic (Bandung) with Technical and Further Education (South Australia) as part of the Sister Province program in West Java and South Australia.

Problem Formulation

Based on the background above, the formulation of the research problem is:

How is the Implementation of Sister Province Cooperation between West Java and South Australia through the collaboration of Institute Fashion Islamic (Bandung) with Technical and Further Education (South Australia)?

Limitation of the Problem

This research, however, is subject to several limitations: 
- This research provides only analytically based on how the process of cooperation between the Institute of Islamic Fashion (Bandung) and Technical and Further Education (South Australia).

- This research provides only analytically based on how the implementation of collaboration between the Institute of Islamic Fashion (Bandung) and Technical and Further Education (South Australia) on the two regions.

\section{LITERATURE REVIEW}

Paradiplomacy

Paradiplomacy is a concept that describes the activities of local government in international relations. Paradiplomacy can also refer to the foreign policy capacity of a sub-state entity, where their participation in the international arena aims to pursue their specific international interests. To achieve its international agenda, local governments open "trade missions" abroad and participate in regional or international organizations and other international networks (ideas for Europe.eu, 2017).

The diplomacy can be carried out by the regional government by formulating a declaration or agreeing to an agreement established with the local government from other countries. The main fields that are generally applied in the paradiplomacy include economic development, technology, education, environment, culture, institutional development, migration, human rights, environment, and security.

The term paradiplomacy was first expressed in the academic debate by Basque scientists, Panayotis Soldatos in the 1980s as a combination of the term 'parallel diplomacy' into 'paradiplomacy' which refers to the meaning of 'the foreign policy of non-central governments' (Wolf, 2009). The diplomacy can be carried out by all sub-state entities of the two countries, both at the city, provincial, or regional level from the federation or unitary countries.

The implementation of paradiplomacy that occurs in developed countries is part of the continuation of the history of integration in their respective countries. This concept can also be linked to the neoliberalism legacy which emphasizes the importance of transnational actors. According to Lecours, the practice of paradiplomacy that they do can be categorized into 3 groups, namely, first the relationship and cooperation of regional or 'sub-state' governments that only aim at the economy such as market expansion, development of foreign investment and mutual investment. This relationship, according to Lecours, only focuses on economics and disregards political or cultural aspects. This international collaboration has been practiced by various states in Australia and the United States. Second, a paradiplomacy which involves various fields in cooperation or 'multipurpose' between economics, culture, education, health and technology transfer, and so on. The concept of cooperative relations refers to the model of foreign cooperation which the country has decentralized or 'decentralized cooperation'. This collaboration has been carried out in several German provinces, and France has intertwined with several states in Africa, Senegal, Tunisia, and several provinces in Vietnam and Poland. Third, a complex paradiplomacy that involves specific political motives and regional nationalist identity. They are trying to establish international relations with enthusiasm to express their national identity in different regions with most regions in their country (Lecours, 2008). 


\section{Sister City / Province}

The concept of sister city/province cooperation in Indonesian is known as a twin city. Twin city in the sense of international cooperation is a collaboration between two cities, provinces or states that have a similar background to the various aspects inherent in both cities such as political aspects, economic, social, geographical, cultural, linguistic, etc., which cross the international or both countries, cooperation Sister City/province builds on agreements between two cities, provincial-level regions, states or prefectures that have one or more similar characteristics where the two regions have two different countries.

The concept of Sister City was created in 1956 at the White House, the United States by President Dwight Eisenhower. Eisenhower. Whereas in the Continent of Europe, the term Twin City is more often used to describe the concept of Twin Cities. The concept of twin cities was first used in continental European countries in the 1920s. This concept was first implemented in the European Continent between the City of Keighley, West Yorkshire, England, and the City of Poix Du Nord, France.

In Indonesia, according to the Indonesian Ministry of Internal Affairs of the concept sister city in a Circulars 93/1652 / PUOD dated 26 April 1993 concerning the Procedures for the Establishment of the Inter-City Cooperation Relations (sister-city) and Inter-Provincial (sister province) in and overseas.

\section{Fashion Diplomacy Concept}

The diplomacy concept had been developed in line with the breadth of the scope of diplomatic activity. Some traditional and modern diplomacy concepts give birth to new concept derivatives that increasingly enrich studies and activities regarding diplomacy. One concept of diplomacy that developed as a new study was fashion diplomacy. Fashion as a part of civilization cannot be neglected in society, politics, arts, education, and academics. The fashion industry also remained as a constant world economy contributor with an annual growth rate of approximately 20 percent (Cao, 2013). Fashion diplomacy is closely related to cultural diplomacy. While in 2007, the term gastronomy began to enter the realm of culture, in 2012, fields such as contemporary art, design, fashion and handicrafts also began to become part of the culture (Carrijo, 2016). The way a person is dressed will be a characteristic of origin, social strata, and can even influence a broad audience. In practice, fashion diplomacy represents non-verbal communication to achieve certain goals.

Lisa Liberatore in her research on public diplomacy explained at least four things in the concept of fashion diplomacy, namely:

1. The use of fashion as a tool to empower women, both as producers or consumers.

2. Representation of an economically and environmentally sustainable style.

3. There is an intersection between fashion and politics.

4. The role of appearance as a tool of international power, both economically and politically.

Even though this concept is fairly new to be studied in studies of diplomacy, fashion practice diplomacy has often been carried out by various countries. For example, the first lady of each country has a big social role in this fashion diplomacy. These first ladies wear clothes with certain brands and identities during diplomatic visits. The importance of fashion diplomacy was 
revealed by the US Secretary of State, John Kerry, who stated that "fashion helps to create a national identity and can provide a platform on which countries can relate to each other".

\section{RESEARCH METHOD}

Qualitative Research Methods

To answer the problem statement in this study, the authors used qualitative research methods. Qualitative research uses what is called naturalistic inquiry by presenting sources in the form of observational notes, in-depth interviews, and related documents in the form of writing or images (Efianingrum, nd). The data used in this study is secondary data or through literature.

\section{FINDINGS AND DISCUSSION}

The Sister Province Cooperation between West Java and South Australia

From the time of independence to the present, West Java has made a major contribution in various fields for the progress of the Unitary State of the Republic of Indonesia. Various achievements at the national and international levels have been successfully inscribed by the province with the largest population in Indonesia. West Java Province, West Java is also one of the first eight provinces formed two days after the proclamation of Indonesian independence.

During the reign of Governor Ahmad Heryawan, the West Java Provincial Government intensively received several prestigious awards from the central government. The governor, who served for two periods, succeeded in increasing the Human Development Index (HDI), GDP, and investment in West Java. In 2017, West Java Province also received the Paramakarya Productivity Award from the Ministry of Manpower of the Republic of Indonesia. (www.pikiran-rakyat.com, 2017).

West Java Province as the third province with the largest population in Indonesia has explored various cooperation sister cities/provinces with regions in other countries to develop regional government development. Sister Province Cooperation between The West Java Provincial Government and South Australia Provincial Government was signed on 17th of April 1997 and began on 21st of August 1997, then a Memorandum of Understanding (MoU) was made between the Governor of West Java, R. Nuriana and Australian Governor, John W. Olsen. The cooperation of sister province among West Java Province and South Australia Province is carried out with the principle of mutual respect for the sovereignty of each of the countries involved so that it limits each country to intervene.

Based on Government Regulation No. 28 of 2018 concerning Regional Cooperation on 12 July 2018, one of which is to regulate Regional cooperation with Local Governments Abroad, it is expected that regional governments can carry out cooperation at the city / province clearer and more targeted under the coordination of the Ministry of Home Affairs, in this is the Center for Cooperation Facilities (www.kemendagri.go.id, 2018).

During the leadership of Governor Ahmad Heryawan, cooperation sister-province in West Java and South Australia was again built. As long as it runs from 2015, as many as 17 programs out of the 22 cooperation programs built through Sister Province have gone well. With the success that 
has been achieved, Ahmad Heryawan wants the collaboration between the West-South Australian Provincial Government to be developed. The revitalization of this collaboration began with the signing of the MoU text between the Deputy Governor of West Java, Deddy Mizwar, and the South Australian Premier, Jay Wetherill at Dunstan Playhouse, Adelaide, South Australia. The signing was witnessed by the Indonesian Consulate General in Sydney as a representative of the central government (www.rmol.id, 2015).

With the formation of this collaboration, it is hoped that it will improve the economic movements of West Java and South Australia by utilizing their respective resources. During the signing of the MoU, the Deputy Governor of West Java and the group were also invited to attend the 201A Australia OzAsia Festival Forum. The OzAsia Festival Forum is Australia's leading international art performance that is fully dedicated to Australia's involvement in Asia. This event is also part of Indonesia-Australia diplomacy activities

IDBC Australia Regional Director Astrid Vasile stated that Sister City or Sister Province between local governments in Indonesia and Australia could help ideal business partners and open business and investment opportunities for business people who want to penetrate the market new. In cooperation with sister-province in South Australia and West Java, the scope of cooperation include agriculture (including fisheries and maritime affairs), education, arts and culture, government cooperation and trade and investment. South Australia is also open to Islamic arts. Like the Art Gallery of South Australia, one of the art galleries in South Australia that displays a large collection of Islamic art. Some programs implemented from the cooperation sister province between South Australia and West Java are related to artistic collaboration.

Several cities have cooperated with Bandung City; those are Braunschweig, Suwon, Hamamatsu, dan Shenzen (http://kerjasama.bandung.go.id/luar-negeri/sister-city\#, 2019). Meanwhile, some of the areas that have Sister Province Cooperation with West Java Province are Chongqing Metropolitan City, Guangxi Zhuang Autonomous Region, Sichuan Province, Heilongjiang Province of the People's Republic of China, and four states of Wallonia Region, Belgium, Japan Shizouku Prefecture, Sudan Khartoum State and Souss Massa Region Morocco.

On January 23-29 2018, the Governor of West Java (Jabar) Ahmad Heryawan made a working visit to South Australia. Through this visit, the West Java Provincial Government expanded the scope of the cooperation program between the West Java Provincial Government and South Australia. The signing of a Memorandum of Understanding (MoU) in Adelaide, South Australia was also carried out as an official step in establishing the Sister Province cooperation in West Java and South Australia at the time of Governor Ahmad Heryawan. The MoU also contained plans to build Public Art Work as installation of artwork for the public in the Gasibu Field area, Bandung. The collaboration is the result of the Adelaide Festival Center Chairman's meeting, Michael Abbot with the Deputy Governor of West Java, Deddy Mizwar. Public Art Work is also a sister province symbol between the West Java Province and South Australia Province.

The Cooperation between Islamic Fashion Institute (IFI), Bandung and Technical and Further Education (TAFE), South Australia

The design of the cooperation planned by West Java and South Australia Provincial Government is carried out through a Joint Working Group Meeting (JWGM). Every year, JWGM is 
held in turns by both parties (radardepok.com, 2017). One of the implementations of the program sister-province that was successfully agreed upon was the collaboration between the Bandung Islamic Fashion Institute and the Technical and Further Education (TAFE) of South Australia. As an implementation of this collaboration, the West Java Provincial Government sent the Bandung IFI Delegation to take part in the Adelaide Fashion Show on October 11-15, 2017. Irna Mutiara as IFI Co-Founder, Euis Saedah as Secretary-General of the Dekranas, attended the IFI event, as well as IFI Trustees and Hanni Haerani as IFI Managers. All representatives of Bandung IFI were received by the Indonesian Consulate General in Sydney.

In the reception, the two parties discussed the plan for developing cooperation, namely student and instructor exchanges, curriculum development, fashion management, media, and the fashion industry, and mastery of English related to the fashion industry. IFI hopes that it's working relationship with South Australia can be more extensive than previously only more in capacity building to be more directed at joint production, joint branding, and joint marketing to bring economic benefits to Indonesia.

On January 24-26 2018, West Java Governor Ahmad Heryawan made a joint working visit to Consulate General Acting, Hermanus, and the Indonesian Consulate Team Sydney to Adelaide to follow up cooperation between West Java and South Australia. In this cooperation visit, the West Java Provincial Government plans to develop a creative economic cooperation sector with South Australia. Seeing significant developments in the digital economy and fintech both in Indonesia and in Australia, cooperation in this field will be very strategic. According to the World Economic Forum (WEF) data, Indonesia has several Startups that grow into unicorns, such as Traveloka, Gojek, and Tokopedia. The development of Startup in Indonesia has attracted the attention of all countries in the world. Consulate General Acting, Hermanus considers that the success of Startup in Indonesia can inspire the development of digital economic ecosystems in Australia and vice versa, Indonesia can learn from Australia from the aspects of regulation, incentives, infrastructure development, and business plans. This cooperation was welcomed by South Australia.

The realization of collaboration Sister Province's between West Java and South Australia Provinces is one of them realized by holding a runway show collaboration between IFI and TAFE at the Adelaide Fashion Festival (AFF) in Adelaide, Australia in November 2018. Previously, IFI and TAFE had also been realizing the exchange of students and instructors from each party. This exchange of students and instructors is also a collaboration capacity building and the realization of knowledge transfer between the two parties. In the event Adelaide Fashion Festival, IFI also presented the work of six young Indonesian designers.

The six IFI students were Anita Yuni Kholillah, Annisa Nur Afrisari, Irma Intan, Aninda Nazmi, Runi Siliwati Legan, and Reyna Hanifa. The event was also attended by Siti Aisyah, Deputy Head of the Indonesia Trade Promotion Center (ITPC) as the representative of the Indonesian Consul General in Sydney, Hanni Haerani, Bandung IFI Manager, and Euis Saedah, IFI Board of Trustees in Bandung. Each designer presented two designs modest wear on the runway show. The event received a warm welcome and praise from the audience. Aaron Rigano as TAFE representative who attended the event expressed his appreciation for the participation of IFI Bandung and hopes that there will be similar collaborations at the annual Adelaide Fashion Festival. In this festival, both IFI and TAFE can be said to have run fashion diplomacy. 
Both Bandung and Adelaide TAFE are known as Creative Cities in their respective countries. In Adelaide, the capital of South Australia, many Indonesian citizens are pursuing their higher education. Moreover, there are two educational institutions in the City of Adelaide, namely, TAFE SA and the Salford College of Business and Hospitality Business School which includes specific subjects regarding Indonesia in the curriculum of both institutions (Pratama, A. 2018). Adelaide, which has the charm of beautiful natural scenery, such as Mount Lofty, Botanical Garden, and other open-air parks, as well as various historic buildings, has invited many tourists. As an effort to bridge the development of modest fashion, Bandung can learn the model of management and technological advances of Adelaide's fashion industry. The collaboration of the runway event show can also be a way to expand their markets.

\section{CONCLUSION}

Conclusion

Sister Province Program between West Java and South Australia is one of the long-standing cooperation. The scope of cooperation between West Java and South Australia covers several aspects, such as agriculture, education, arts and culture, government cooperation, and trade and investment. One realization of the cooperation between the Sister Province of West Java and South Australia is related to the arts and culture, especially concerning fashion. This cooperation was established between the Islamic Fashion Institute (IFI), located in the capital city of West Java, Bandung, and TAFE, located in the capital city of South Australia, Adelaide.

Both Bandung and Adelaide, these two cities are known as creative cities. The forms of cooperation that have been implemented between IFI and TAFE are student exchanges and instructors, and fashion show collaborations. However, the implementation of cooperation between IFI and TAFE can be said to be still in the process of building, several cooperation plans such as joint production, joint branding, and joint marketing are still not fully realized. This cooperation has not yet materialized because the period of cooperation between them is still relatively new and both still need to prepare for more comprehensive preparation and infrastructure to further strengthen cooperation and mutual benefit from each other.

Bandung is the capital city of West Java, which is one of the cities that is a fashion mecca in Indonesia also needs to consider local wisdom which will be a mission to be brought to foreign countries. The development of modest fashion and covered clothing in Indonesia has also become a strategic point to expand the fashion industry market which can boost the Indonesian economy. Also, Australia's proximity to Indonesia, especially in terms of multicultural culture and its democratic society can be a gap to facilitate both parties in establishing sustainable cooperation, even in other fields. West Java and Australia also share a high degree of relevance to the creative industry, so it is not uncommon for the two regions to collaborate in various arts and cultural events held in their respective countries. The establishment of the Public Art Work and the collaboration of IFI-TAFE between West Java and South Australia also became a sign that there was close cooperation between the two regions. Governments from each region also need to look at other strategic cooperation gaps and respond actively to the development of such cooperation. Thus, sister province cooperation between West Java and South Australia can run more effectively and obtain satisfactory results. 


\section{Suggestion}

Based on the research that has been done on the cooperation between IFI and TAFE as the implementation of the sister province program between West Java and South Australia, several things that have not been studied are the need to increase the trade activities in the textile sector between West Java and South Australia, and other fashion events that held by the two regions.

\section{REFERENCES}

Berridge, G. (2010). Diplomacy: Theory and Practice. New York: Palgrave.

Lecours, A. (2008). Political Issues of Paradiplomacy: Lessons from the Developed World. Clingandael: Netherlands Institute of International Relations.

Scholte, J. (2000). Globalization: A Critical Introduction. Londong: Macmilan.

Wolf, S. (2009). Paradiplomacy:Scope, Opportunities and Challenges. Nottingham: Univesity of Nottingham.

Nilawati, H.N. (2016). Pelaksanaan Program Sister City dalam Perspektif Sound Governance: Studi Kasus Kota Surabaya. Kebijakan dan Manajemen Publik. Vol. 4, No. 2, Mei-Agustus 2016.

Nuralam, I. (2018). Peran Strategis Penerapan Konsep Sister City dalam Menciptakan Surabaya Green City. Journal of Applied Business Administration, Vol. 2, No.1, Maret 2018. Page 144-151

Nurika, R. R. (2017, Januari-Juni Vol 1). Peran Globalisasi di Balik Munculnya Tantangan Baru Bagi Diplomasidi Era Kontemporer. Jurnal Sospol, pp. Page 126-141.

Cao Z, Gao H, Qu X, Yang M, Yang X (2013) Fashion, Cooperation, and Social Interactions. PLoS ONE 8(1): e49441. https://doi.org/10.1371/journal.pone.0049441

Kim, H. (2017). Bridging the Theoretical Gap between Public Diplomacy and Cultural Diplomacy. The Korean Journal of International Studies. Vol.15, No.2. Page 293-326.

Dissertation

Carrijo, F.B (2016) A Theoretical and Methodological Proposal in Cultural Diplomacy Analysis: The Case of the Brazilian Cultural Centre in Barcelona (2003-2013). Universitat Autonoma de Barcelona.

Diakses

dari: (https://www.tesisenred.net/bitstream/handle/10803/392699/fbc1de1.pdf?sequence=1\&is Allowed=y)

Firhand, A, \& Hariyanto. (2018). Indonesia Encourages Cooperation of Fashion and Fintech with Australia. Diakses dari: (http://en.industry.co.id/read/3479/indonesia-encouragescooperation-of-fashion-and-fintech-with-australia) [14 Mei 2019]

Lisa Liberatore. 2013. 2013 Forum on Public Diplomacy at USC by APDS. Dalam http://www.youtube.com/watch?v=CfWVOC_XJak [23 Mei 2019]

Marie. (2017) What is Fashion Diplomacy. Diakses dari: (http://fashionadresse.com/what-is-thefashion-diplomacy/) [23 Mei 2019]

Nursalikah, A. (2016) Karya Seni Islam Indonesia Dipamerkan di Adelaide. Diakses dari: https://internasional.republika.co.id/berita/internasional/abc-australianetwork/o8fapl366/karya-seni-islam-indonesia-dipamerkan-di-adelaide [16 Mei 2019]

Pratama, A. (2018) Budaya Indonesia Jadi Mata Pelajaran Pilihan di Sekolah Australia. Diakses dari: (https://merahputih.com/post/read/budaya-indonesia-jadi-mata-pelajaran-pilih-di-sekolahaustralia) [18 Mei 2019] 
Ramadhan, D. (2018) 10 Tahun Pimpin Jawa Barat, Aher: Alhamdulillah Raih Banyak Prestasi. Diakses dari: (https://news.detik.com/berita-jawa-barat/d-4067737/10-tahun-pimpin-jawabarat-aher-alhamdulillah-raih-banyak-prestasi) [14 Mei 2019]

Sarasa, A. (2018). Kerja Sama Sister Province Jawa Barat-Australia Selatan Akan Diperluas. Diakses dari: (https://daerah.sindonews.com/read/1277740/21/kerja-sama-sister-province-jawabarat-australia-selatan-akan-diperluas-1517233065) [16 Mei 2019]

Gubernur Australia Selatan Maunya Kerjasama dengan Jawa Barat Segera Terlaksana. Diakses dari: (https://www.rmol.id/read/2015/09/25/218682/Gubernur-Australia-Selatan-MaunyaKerjasama-dengan-Jawa-Barat-Segera-Terlaksana-) [18 Mei 2019]

Australia Selatan Kerjasama dengan Jawa Barat. (2017) Diakses dari: (https://radardepok.com/2017/01/australia-selatan-kerjasama-dengan-jawa-barat/) [18 Mei 2019]

Go Internasional, Sekolah Fashion Muslim IFI Rambah Australia. Diakses dari (https://chanelmuslim.com/fashion/go-internasional-sekolah-fashion-muslim-ifi-rambahaustralia) [14 Mei 2019]

Indomedia Australia. (2018) Memperkuat Koneksi Kota Kreatif Bandung-Adelaide. Diakses dari: https://indomedia.com.au/memperkuat-koneksi-kota-kreatif-bandung-adelaide/ $\left[\begin{array}{ll}16 & \text { Mei }\end{array}\right.$ 2019]

Jabar dan Australia Selatan Kerjasama Sister Province. Diakses dari: (https://www.liputan6.com/news/read/2909238/jabar-dan-australia-selatan-kerjasamasister-province) [14 Mei 2019]

Setiap 13 Hari Sekali, Pemprov Jabar Raih Penghargaan. Diakses dari: (https://www.pikiranrakyat.com/jawa-barat/2017/12/12/setiap-13-hari-sekali-pemprov-jabar-raih-penghargaan415742 ) [17 Mei 2019]

Tingkatkan Hubungan Sister City/Province dengan Australia, IDBC dan Kemendagri Teken MoU. Diakses dari: (https://www.kemendagri.go.id/blog/27726-Tingkatkan-Hubungan-SisterCityProvince-dengan-Australia-IDBC-dan-Kemendagri-Teken-MoU) [17 Mei 2019]

Wijoyo, A. (2015). Sister City, Jabar Perkuat Kerja Sama dengan Australia. Diakses dari: (https://www.merdeka.com/peristiwa/sister-city-jabar-perkuat-kerja-sama-denganaustralia.html) [14 Mei 2019]

(MINA), M. N. (2017, November 4). Bandung Islamic Fashion Institute Kerjasama dengan Australia Selatan. Retrieved from minanews.net: https://minanews.net/bandung-islamic-fashioninstitute-kerjasama-dengan-australia-selatan/

Bandung, B. K. (2019, Januari 3). Sister City. Retrieved from Awal Mula dan Sejarah Kerjasama Sister City: kerjasama.bandung.go.id/luar-negri/sister-city

Ariefa Efianingrum (n.d.) Metode Penelitian Kualitiatif dan Kuantitatif. Seminar Sosiologi Indonesia. 